\title{
Performance of broiler chickens fed different animal protein sources as replacement for fish meal
}

*Egbewande, O. O., Mawoli, M. N. and Lawal, B.

Faculty of Agriculture, Department of Animal Production,

Ibrahim Badamasi Babangida University, Lapai, Niger State, Nigeria

*Corresponding author: femi2015.ooe@gmail.com; +2347068233925

\section{Abstract}

Searching for least cost feed component should be extended to unconventional feedstuffs that are locally available and cheaper to come by. Therefore, an eight-week experiment was carried out to determine the effect of different protein sources (maggot, termite, grasshopper and lizard meal) on performance of broiler chickens. A total of one hundred and fifty (150), one day-old broiler chicks of Marshall Breed were used for the experiment. An eight-week study was conducted to evaluate the performance of broiler chickens fed the four different sources of animal protein. Diet I contained 5\% fish meal while Diets 2, 3, 4 and 5 contained 5\% maggot meal, termite meal, grasshopper meal and lizard meal, respectively at the starter phase. The finisher phase contained $2.5 \mathrm{~kg}$ each of the protein sources respectively. The chicks were allotted to five dietary treatments each replicated thrice with ten birds per replicate in a completely randomized design (CRD). Proximate composition of the test ingredients showed that lizard meal had the highest (55.66\%) crude protein and crude fibre (5.53\%). Termite meal exhibited highest (26.46\%) ether extract followed by maggot meal (9.79\%) with the lowest (4.02\%) from lizard meal. The feed intake value (4700.16g) in birds fed diet 1 was significantly $(P<0.05)$ higher than others. Birds fed Diet 2 showed significant $(P<0.05)$ better final weight gain (2367g) than those fed other test ingredients. Birds fed diet 2 (maggot meal) performed better than others in absolute weight gain (2287g) which is very close to those fed fish meal (Diet 1). In conclusion, maggot meal in this study enhanced performance and is thus recommended as a replacement for fish meal.

Key words: Animal protein, broiler, performance, proximate composition

\section{Introduction}

There is a stiff competition for conventional energy and protein feedstuffs (the most expensive part of animal feed), by man and animals, and this has led to increase in their prices (Onu and Madubuike, 2007), and invariably high prices of animal products. In order to save the populace from impending malnutrition, there is a dire need to explore alternative sources of energy and protein feedstuffs (Van Huis, et al., 2013), to reduce the cost of production. According to the report of Esonu, et al. (2006), the hike in the prices of conventional feed ingredients is a major factor affecting net returns of poultry business. Therefore, to reduce the feed cost which accounts for at least $70 \%$ of the total cost (Nworgu, et al., 1999), research efforts should be geared towards evaluating alternative feed ingredients for poultry birds. The search for the least cost feed component is currently exploring the replacement of those conventional feedstuffs with cheaper and locally available alternatives in the formulation of poultry feed. High cost of fish meal has led researchers into unexplored alternative sources such as live maggot and maggot meal which has no competition between man and animal (Awoniyi, et al., 2003). In support of this, Atteh and Ologbenla (1993) reported that alternatives should have comparative nutritive value, be cheaper than the conventional protein sources and be available in larger quantities. This makes the prospects of utilizing maggot, termite, grasshopper and lizard meals as alternative 


\section{Performance of broiler chickens fed different animal protein sources}

sources for fish meal a visible and promising one. Fish meal could be replaced at $100 \%$ inclusion rate by maggot meal which has been accredited for its quality protein value (Egbewande, et al., 2017). Grasshopper meal, one of the locally available alternatives can also completely replace fish meal in broiler diets without affecting their biological performance and economic returns (Muftau and Olorede, 2009). Termite meal is also one of the available alternatives with high protein and various enzymes including cellulose enzymes produced by microbes in its digestive system (Ketaren, et al., 2001). Lizard meal is another cheap and locally available alternative. Lizard meal is superior in nutrients compared to other unconventional animal protein sources such as locust and grasshopper meals (Ogunji, 2004). Olabode, et al. (2017) reported that lizard meal as protein source enhanced broiler chickens growth and reduce cost of production. It is from the above that this study compared maggot, termite, grasshopper and lizard meals as alternative protein sources with fish meal in broiler diets.

\section{Materials and methods Experimental site}

The experiment was conducted at the Poultry Unit of the Teaching and Research Farm, Ibrahim Badamasi Babangida University, Lapai Niger state. The area is located in the vegetative zone of guinea savannah, middle belt of Nigeria. It lies on longitude $9.02^{\circ} \mathrm{N}$ and latitude $6.3^{\circ} \mathrm{E}$ of the equator with an average temperature range of $21^{\circ} \mathrm{C}-36.5^{\circ} \mathrm{C}$ and a rainfall range of 1100-1600mm (Usman, 2013).

Source and preparation of test ingredients

Maggots used in this experiment were bred from layers droppings sprinkled with blood.
They were obtained by culturing housefly larvae on the droppings. The droppings were spread on a wet platform in order to attract houseflies (Musca domestica) which introduced the larvae on the dropping. After seven days, they were ready for harvesting, as they migrate to the surface of the substrate. The harvested maggots were oven-dried at $75^{\circ} \mathrm{C}$ for three hours in order to reduce its moisture content for proper storage. The dried maggot was milled and a sample of the meal was taken to the laboratory for determination of the proximate composition according to A.O.A.C (2005). The winged adult termites (Macrotermes bellicossus) were caught using net and broom while on their nuptial flight and, handpicked from the ground for those that have shed their wings. Male and female Agama agama lizards (mature) were caught by hunting with catapults, stones and traps. Care was taken to avoid much damage to the carcass during hunting and trapping. The lizards were slaughtered and their visceral removed. Lizard carcass was sundried for 12 days to appreciable moisture content in the month of December. Dried grasshoppers were purchased from Lapai local market. The carcass of Agama agama lizard, dried termite and grasshopper were later ground into meal using hammer mill into separate bags, and later taken to laboratory for determination of the proximate composition according to the procedures ofA.O.A.C (2005).

\section{Experimental diets}

The experimental starter diets (Table 1) composed of $5 \%$ fish meal as source of animal protein in diet 1 (control), $5 \%$ of maggot meal (MGM), termite meal (TMM), grasshopper meal (GHM), and lizard meal (LDM) in diets 2, 3, 4 and 5 respectively. At the finisher phase, $2.5 \%$ of each test ingredient replaced fish meal in diets 2, 3, 4 and 5 respectively (Table 1 ). 
Egbewande, Mawoli and Lawal

Table 1: Gross composition of experimental diets

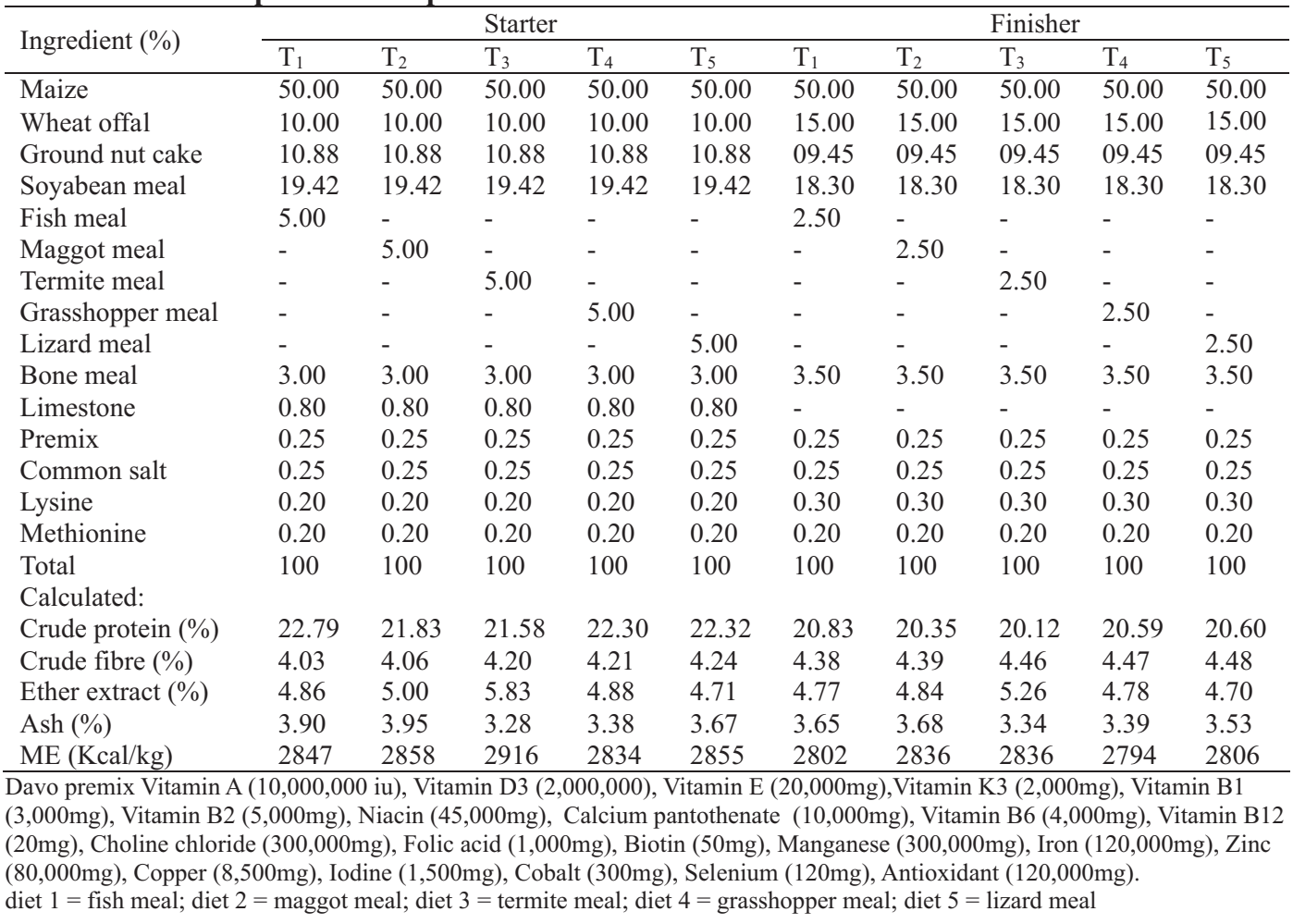

\section{Experimental birds and husbandry}

The pens were cleaned and disinfected with Izal before the arrival of the chicks. A total of one hundred and fifty (150) day-old broiler chicks of Marshal Breed were used for the study. They were allotted into five treatments of 30 chicks each in a completely randomized design (CRD). Each treatment was replicated thrice with 10 birds each. The chicks on arrival were placed on the experimental diets. They were brooded on deep litter using charcoal as source of heat. Anti-stress (Vitalyte ${ }^{\circledR}$ ) was administered to the chicks on arrival and routine management practices were adopted as recommended by Oluyemi and Roberts (2000). Experimental broiler starter feed was fed in the first four (4) weeks while experimental broiler finisher was fed in the last four (4) weeks. Feeds and water were supplied ad-libtum. The birds were vaccinated against gumboro disease at the end of weeks 1 and 3, using infectious bursal disease vaccine (IBDV) and Newcastle disease vaccine (Lasota) at the end of $2^{\text {nd }}$ and $4^{\text {th }}$ weeks. Amprollium ${ }^{\circledR}$ was administered to the birds against coccidiosis at week 5 .

\section{Data collection}

Proximate compositions (crude protein, crude fibre, ether extract, ash, dry matter and moisture) of the test ingredients were determined according to the procedures of AOAC (2005). Nitrogen free extract (NFE) was determined by difference, while the metabolizable energy (ME) was calculated according to the formula of Pauzenga (1985) as:

$M E(\mathrm{kcal} / \mathrm{kg} \mathrm{DM})=[(37 \times \%$ Protein $)+$ $(81.8 x \% E E)+(35.5 x \% N F E)]$

Organic matter (OM) of the test materials was obtained by subtracting \%ash content from $100 \%$. Data on body weight gain and feed intake were collected on weekly basis 


\section{Performance of broiler chickens fed different animal protein sources}

and these were used to determine feed conversion ratio (FCR). Feed intake was monitored by finding the differences between the served and leftover quantities. The mean value of these parameters were obtained and recorded. The data were further used to obtain the following:

Mean final weight gain = mean final weight - mean initial weight

Feed conversion ratio $=$ mean daily feed intake

mean daily weight gain

Mortality $(\%)=$

number of dead birds $x 100$

initial number of birds

The study lasted for eight weeks and mortality was recorded as it occurred throughout the period of the experiment.

\section{Statistical analysis}

Data collected were subjected to one-way analysis of variance (ANOVA) according to the procedure of Steel and Torrie (1980). The significant means were separated using Duncan's Multiple Range Test (DMRT) (Duncan, 1955) at 5\% probability level.

\section{Results}

Table 2 showed the proximate composition of maggot, termite, grasshopper and lizard meals. Dry matter content of the test ingredients were 91.87, 92.94, 93.05 and $95.52 \%$ for the test ingredients respectively. Crude protein contents were 45.84, 36.67, 35.23 and $55.66 \%$ for maggot, termite, grasshopper and lizard meals respectively. The values of crude fibre in this study for maggot, termite, grasshopper and lizard meals were 1.97, 4.88, 5.03 and 5.53\% respectively. The values for ash ranged from $4.55 \%$ in termite meal to $17.93 \%$ in maggot meal. Those of ether extract in this study ranged from $4.02 \%$ in lizard meal to $26.46 \%$ in termite meal. Nitrogen free extract (NFE) of the test ingredients ranged from $16.34 \%$ in maggot meal to $20.38 \%$ in termite meal. Organic matter in the test materials ranged from $82.07 \%$ in maggot meal to $95.45 \%$ in termite meal, while metabolizable energy (ME) ranged between 3029.39 in lizard meal and $4244.71 \mathrm{kcal} / \mathrm{kg} \mathrm{DM}$ in termite meal.

Table 2: Proximate composition of the test ingredients

\begin{tabular}{lllll}
\hline Proximate (\%) & Maggot meal & Termite meal & Grasshopper meal & Lizard meal \\
\hline Dry matter & 91.87 & 92.94 & 93.05 & 95.52 \\
Moisture & 8.13 & 7.06 & 6.95 & 4.48 \\
Crude protein & 45.84 & 36.67 & 55.23 & 55.66 \\
Crude fibre & 1.97 & 4.88 & 5.03 & 5.53 \\
Ash & 17.93 & 4.55 & 6.62 & 12.25 \\
Ether extract & 9.79 & 26.46 & 7.36 & 4.02 \\
Nitrogen free extract & 16.34 & 20.38 & 18.81 & 18.06 \\
Organic matter & 82.07 & 95.45 & 93.38 & 87.75 \\
Metabolizable energy $(\mathrm{kcal} / \mathrm{kg})$ & 3076.97 & 4244.71 & 2573.31 & 3029.39 \\
\hline
\end{tabular}

Performance of broiler chickens fed test ingredients

The performance of broiler birds fed diets containing different animal protein sources is shown on Table 3 . The final weight gain showed significant $(\mathrm{P}<0.05)$ differences and were recorded as 2400, 2367, 2167, 2167 and $1930 \mathrm{~g}$ for treatment 1, 2, 3, 4 and 5 respectively. Absolute weight gains showed no significant $(\mathrm{P}>0.05)$ differences and were recorded as 2324, 3387, 2091, 2097 and $1857 \mathrm{~g}$ for treatment $1,2,3,4$ and 5, respectively. Feed intake showed significant $(\mathrm{P}<0.05)$ differences and ranged from $4289.89 \mathrm{~g}$ in birds fed lizard meal to $4700.16 \mathrm{~g}$ in birds fed control diet, while average daily feed intake ranged from $76.60 \mathrm{~g}$ in birds fed lizard meal to $83.93 \mathrm{~g}$ in birds fed control diet. Feed conversion ratio was at the best (2.02) in birds fed control diet, followed by those fed maggot meal (2.04), and the worst (2.31) from those fed lizard meal. Mortality was obtained as 3.33, $3.33,6.67,6.67$ and $13.30 \%$ for treatments $1,2,3,4$, and 5 , respectively. 
Egbewande, Mawoli and Lawal

Table 3: Mean values for performance traits of chickens fed the different protein sources

\begin{tabular}{llllllll}
\hline Parameter & Diet 1 & Diet 2 & Diet 3 & Diet 4 & Diet 5 & SEM & P-value \\
\hline Initial LW $(\mathrm{g})$ & 76.00 & 80.00 & 76.00 & 70.00 & 73.00 & 0.13 & $<0.001$ \\
Final LW $(\mathrm{kg})$ & $2.40^{\mathrm{a}}$ & $2.37^{\mathrm{b}}$ & $2.17^{\mathrm{c}}$ & $2.17^{\mathrm{c}}$ & $1.93^{\mathrm{d}}$ & 0.40 & $<0.001$ \\
LW gain $(\mathrm{g} / \mathrm{d})$ & 41.50 & 40.80 & 37.30 & 37.40 & 33.20 & 0.02 & $<0.001$ \\
Feed intake $(\mathrm{kg})$ & $4.70^{\mathrm{a}}$ & $4.66^{\mathrm{a}}$ & $4.35^{\mathrm{b}}$ & $4.44^{\mathrm{b}}$ & $4.29^{\mathrm{c}}$ & 0.08 & $<0.001$ \\
ADFI $(\mathrm{g})$ & 83.93 & 83.23 & 77.67 & 79.27 & 76.60 & 0.21 & $<0.001$ \\
FCR & 2.02 & 2.04 & 2.08 & 2.12 & 2.31 & 0.09 & 0.02 \\
Mortality (\%) & 3.33 & 3.33 & 6.67 & 6.67 & 13.3 & & \\
\hline
\end{tabular}

abcd Means within the same row with different superscripts differ at $p<0.05$; SEM: standard error of mean; FCR: feed conversion ratio, $\mathrm{ADFI}=$ average daily feed intake, $\mathrm{LW}=$ live weight

\section{Discussion}

Crude protein, crude fibre, ether extract and ash contents of maggot in this study were higher than the 44.44, 1.83, 9.76 and $14.29 \%$ reported by Okah and Onwujiariri (2012) for the same proximate parameters respectively. Crude protein for maggot meal in this study was lower than 63.99 and $48 \%$ reported by Hwangbo, et al. (2009) and Odesanya, et al. (2011) respectively, but were quite the same with $45 \%$ reported by Fasakin, et al. (2003). The differences may be due to maturity stage of the maggot as reported by Chapman (1971), that the nutrients in housefly larvae depend upon the maturity stage of the larvae at harvest. It may also be due to differences in the analysis procedures employed and probably the medium used in culturing the maggots as reported by Hwangbo, et al. (2009). The termite sample contents of protein and ether extract in this study were 36.67 and $26.46 \%$ respectively. That value for termite protein is lower than $46.3 \%$ reported by Sogbesan and Ugwumba (2008), and 58.20\% reported by Oyarzun, et al. (1996), but higher than $21.25 \%$ reported by Banjo, et al. (2006). The ether extract value was lower than $34.23 \%$ recorded by Igwe, et al. (2011), but higher than 15.04\% reported by Oyarzun, et al. (1996). The differences in the values may be due to the species of termite used for different studies. The values of crude protein obtained in this study for grasshopper meal was higher than $47.73 \%$ reported by Brah, et al. (2018) for Ornithacris cavroisi but lower than $62.73 \%$ reported by Ademolu, et al. (2010) for Zonocerus variegatus species. Values on lizard meal revealed that the crude protein, crude fibre and ether extract obtained in this study were lower than the reported values of $59.61,14.95$ and $8.58 \%$ respectively of Tiamiyu, et al. (2014), but the ether extract and crude fibre values were higher than the reported values of 2.79 and 2,15\% respectively of Abulude, et al. (2007). Crude protein value obtained in this study was very close to the authors' report $(55.87 \%)$. There were significant $(\mathrm{P}<0.05)$ differences among the treatments mean of feed intake. Birds on diet 1 (control) had the highest feed intake value (4700.16g), followed by those on diet 2 (4661.31g) which was not significantly $(\mathrm{P}>0.05)$ different statistically from birds fed fish meal. This was similar to the report of Egbewande, et al. (2017), who obtained no significant $(\mathrm{P}>0.05)$ effect when maggot meal was used to replace fish meal in diets of broiler chickens. There was a reduced feed intake compared with control diet although no significant $(\mathrm{P}>0.05)$ difference between the two group. This agreed with the report of Awoniyi, et al. (2003) that there was no significant effect in feed intake of control and those fed maggot meal. The daily feed intake observed in this experiment for broiler chickens fed grasshopper meal was not so far from results reported by Brah, et al. (2018), who substituted fish meal with grasshopper meal (Ornithacris cavroisi) in broiler diet, and Adeyemo, et al. (2008) who fed broilers 


\section{Performance of broiler chickens fed different animal protein sources}

with desert locust meal (Schistocerca gregaria). Average weight gain from birds fed grasshopper meal was lower than those fed control. The decreased growth performance may be attributed to chitin content of grasshopper which is in line with the report of Khempaka, et al. (2011) that chitin may decrease the digestibility because of a non-digestible amino polysaccharide. The lowest final weight $(1930 \mathrm{~g})$, feed intake $(4289.89 \mathrm{~g})$, absolute weight gain $(1857 \mathrm{~g})$, and the highest mortality rate $(33.33 \%)$ obtained in birds fed lizard meal may be as a result of the anti-nutritional factors in raw lizard as reported by Abulude, et al. (2007). The authors reported that raw Agama agama lizard contained tannin, oxalate and phytate. The final weight gain obtained from birds fed lizard meal in this study is however, higher than $1526 \mathrm{~g}$ reported by Olabode, et al. (2017). Feed conversion ratios of 2.02 and 2.04 for birds on Diets 1 and 2 respectively were superior compared with the rest treatment groups. The worst FCR obtained in birds fed raw lizard meal may also be due to the presence of antinutrients contained in the raw lizard carcass. The value obtained in this experiment was however better than 2.35 reported by Olabode, et al. (2017) when processed lizard meal was fed to broiler chickens at $100 \%$ level of inclusion.

\section{Conclusion}

This study revealed that maggot meal can completely replace fish meal at 100\% inclusion level in broiler chicken diet without any significant effects on weight gain, feed intake and feed conversion ratio. The performance of birds on ${ }^{\text {Diet }} 2$ revealed that maggot meal can serve as an alternative animal protein source to fish meal. Since growth is of paramount concern to poultry farmers, the performance of birds fed Diet 2 (maggot meal) seemed to indicate better nutrient adequacy than diets 3,4 and 5 and is therefore, recommended. However, Agama agama lizard should undergo processing method(s) so as to reduce the anti-nutrients in the carcass.

\section{References}

Abulude, F. O., Adesanya, W. O., Ogunkoya, M. O., Onibon, V. $\mathrm{O}$. and Ajayi, E. 2007. Compositional Studies on Tropical Species of Agama agama Lizards . International Journal of Zoological Research, 3(4): 218 222.

Ademolu, K. O., Idowu, A. B. and Olatunde, G. O. 2010. Nutritional value assessment of variegated grasshopper (Zonocerus variegatus L.) (Acridoidea: Pygomorphidae) during post-embryonic development. Afr. Entomol., 18(2): $360-364$.

Adeyemo, G. O., Longe, O. G. and Lawal, H. A. 2008. Effects of feeding desert locust meal (Schistocerca gregaria) on performance and haematology of broilers. Tropentag, 7-9 October 2008, Hofenheim, Germany. Retrieved $\begin{array}{lllll}\mathrm{f} & \mathrm{r} & \mathrm{O} & \mathrm{m}\end{array}$ http://www.tropentag.de/2008/abst acts/abstracts.phpfishowtime= 0 \&no ID $=1 \&$ menu $=11$

A.O.A.C. 2005. Association of Official Analytical Chemists. Official Methods of Analysis. $18^{\text {th }}$ edition, AOAC, Inc. Arlington, Virginia, USA.

Atteh, J. O. and Ologbenla, S. 1993. Replacement of fish meal with maggots in broiler diets: Effect on performance and nutrient retention. Nigerian Journal of Animal Production, 20(1): 44-49.

Awoniyi, T. A. M., Aletor, V. A. and Aina, J. M. 2003. Performance of broiler chicken fed on maggot meal in 
place of fish meal. International Journal of Poultry Science, 2(40): 271- 274.

Banjo, A. D., Lawal, O. A. and Songonuga, E. A. 2006. The nutritional value of fourteen species of edible insects in southwestern Nigeria. African Journal of Biotechnology, 5: 298301.

Brah, N., Houndonougbo, F. M. and Issa, I. 2018. Grasshopper meal (Ornithacris cavroisi) in broiler diets in Niger: Bioeconomic performance. International Journal of Poultry Science, 17: 126 $-133$.

Chapman, R. F. 1971. The insect structure and function. American Elsevier Publishers Co.Inc. New York, U.S.A.

Duncan, D. B. 1995. Multiple Range and Multiple F-tests Biometrics 11: 142.

Egbewande, O. O., Jimoh, A. A. and Amore, B. T. 2017. Performance and slaughter characteristics of broiler chickens fed different sources of maggot meal. Nigerian Journal of Animal Production, 44(2): $262-270$.

Esonu, B. O., Opara, M. N., Okoli, I. C., Obikaonu, H. O., Udedibie, C. and Iheshiulor, O. O. M. 2006. Physiology response of laying birds to neem (Azadirachta indica) leaf meal based diets. http://www.ojhas.org/issue $18 / 200$ 6-2-4.htm.

Fasakin, E. A., Balogun, A. M. and Ajayi, O. O. 2003. Nutrition implication of processed maggot meal, hydrolyzed, defatted, full-fat, sundried and oven-dried in the diets of Clarias gariepinus fingerlings, Aquaculture Research, 9(34): 733-738.
Hwangbo, J., Hong, E. C., Jang, A., Kang, H. K., Oh, J. S., Kim, B. W. and Park, B. S. 2009. Utilization of housefly-maggots, a feed supplement in the production of broiler chickens. Journal of Environmental Biology, 30(4): 609 $-614$

Igwe, C. U., Ujowundu, C. O., Nwaogu, L. A. and Okwu, G. N. 2011. Chemical analysis of an edible African termite, Macrotermes nigeriensis: a potential antidote to food security problem. Biochemistry and Analytical Biochemistry, 1:105, doi: 10,4172/2161- 1009,1000105

Ketaren, A. P., Simurat, A. P., Purwadaria, T., Kanpiang, I. P. and Amir, M. 2001. Use of termite as poultry feed. Indonesian Journal of Animal and Veterinary Sciences, 6(2):

Khempaka, S. Chitsatchapong, C. and Molee, W. 2011. Effect of chitin and protein constituents in shrimp head meal on growth performance, nutrient digestibility, intestinal microbial populations, volatile fatty acids and ammonia production in broilers. J. Applied Poult. Res., 20: 1-11.

Muftau, M. A. and Olorede, B. R. 2009. Carcass characteristics and economics of broiler chickens fed different levels of grasshopper meal in place of fish meal. Journal of Animal Production Research Advances, 5(4): 248 251.

Nworgu, F. C. 2007. Economics importance and growth rate of broiler chickens served fluted pumpkin leaves extract. African Journal of Biotechnology, 6(2): 22 -34 .

Odesanya, B. O., Ajayi, S. O., Agbaogun, 
B. K. O. and Okuneye, B. 2011. Comparative evaluation of nutritive value of maggots. International Journal of Scientific and Engineering Research, 2(11): $1-5$.

Ogunji, J. O. 2004. Alternative protein sources in diet for farmed tilapia. Animalscience.com review. No 13, Nutrition abstract and review, 74(8): 23-32

Okah, U. and Onwujiariri, E. B. 2012. Performance of finisher broiler chickens fed maggot meal as a replacement for fish meal. International Journal of Agricultural Technology, 8(2): 471-477.

Olabode, A. D., Ugwuowo, I. C., Agu, C. I. and Ojuoloruntaye, P. J. 2017. Lizard meal as protein source enhanced broiler growth and reduce cost of production in Ishiagu, Ivo Local Government Area, Ebonyi State. Nigerian Journal of Animal Production, 44(5): $99-103$.

Oluyemi, J. A. and Roberts, F. A. 2000. Poultry Production in Warm Wet Climates. $2^{\text {nd }} \quad$ Edition, Spectrum Book Limited, Ibadan, Oyo State, Nigeria.

Onu, P. N. and Madubuike, F. N. 2007. Effects of raw and cooked wild cocoyam (Calaium bicolar) on the performance of broiler chicks, Int. J. Poult. Sci., 39:268-273.

Oyarzun, S. E., Crawshaw, G. J. and Valdes, E. V. 1996. Nutrition of Tamandua: Nutrient composition of termites (Nasutitermes spp.) and stomach contents from wild Ta m a du a (Tamandua tetradactyla). Zoo Biol. 15:509 524.
Pauzenga, U. 1985. Feeding Parent Stock. Zootech International. Pp. 22-25.

Sogbesan, A. O. and Ugwumba, A. A. A. 2008. Nutritional evaluation of termite (Macrotermes subhyalinus) meal as animal protein supplements in the diets of Heterobranchus longifilis (Valenciennes, 1840) fingerlings. Turkish Journal of Fisheries Aquat. Sci., 8: 149-157.

Steel, R. G. D. and Torrie, J. H. 1980. Principles and Procedures of Statistics. A Biometrical Approach. $2^{\text {nd }}$ ed., McGraw-Hill Publications. New York.

Tiamiyu, L. O., Okomoda, V. T. and Oko, P. 2014. Proximate composition and amino acid profile of Agama agama meal: Implications for fish nutrition, Octa Journal of Biosciences, 2(1): 28-31.

Usman, B. A. 2013. Vulnerability and adaptation capability of the rural poor farmers to climate change effect in Kwara State, Nigeria. Lapai Sociological Review, 4(1): $142-162$.

Van Huis, A., VanItterbeeck, J., Klunder, H., Mertens, E., Halloran, A., Muir, G. and Vantomme, P. 2013. Edible insects future prospects for food and feed security. -FAO Forestry Paper 171.

Received: $14^{\text {th }}$ October, 2019 Accepted: $19^{\text {th }}$ February, 2020 